\title{
Optimization of Biostimulants Application for Phenology and Quality of Oats
}

Zulfiqar Ali Gurmani $i^{1,2}$

https://orcid.org/0000-0003-0933-4157

Samiullah Khan ${ }^{1}$

https://orcid.org/0000-0002-2520-3635

Ayub Khan ${ }^{1}$

https://orcid.org/0000-0002-9375-3209

\author{
Abid Farid ${ }^{1}$ \\ https://orcid.org/0000-0001-8130-170X
}

Sajjad Khan ${ }^{2}$

https://orcid.org/0000-0001-6235-0151

Muhammad Usama Hameed ${ }^{2}$

https://orcid.org/0000-0002-1943-4381

${ }^{1}$ University of Haripur, Department of Agriculture, Haripur, Pakistan; ${ }^{2}$ Crop Science Institute, Pakistan Agricultural Research Council, Islamabad, Pakistan.

Editor-in-Chief: Alexandre Rasi Aoki

Associate Editor: Ivo Mottin Demiate

Received: 2020.11.17; Accepted: 2021.05.02.

${ }^{*}$ Correspondence:uh_joiya@hotmail.com; Tel: +925190733533 (M. U. H.).

\section{HIGHLIGHTS}

- Chitosan 100 ppm is better than other concentrations for oat yield and quality.

- Application of moringa leaf extract ratio at1:40 produced better yield, CP and minerals in oats.

- For oat yield and quality traits, application of sea weed extract at $2 \%$ and thiourea $400 \mathrm{ppm}$ performed better than other traits.

- Overall, fodder yield and quality parameters were enhanced by the application of biostimulants.

Abstract: In modern agriculture the use of biostimulants not only reduces the cost of production but also increase yield and quality of crops without harming environment. The response of fodder oat to biostimulants was evaluated in a pot experiment using four biostimulants at different concentrations i.e Moringa leaf extract at ratio of $1: 10,1: 20,1: 30,1: 40,1: 50$, Sea weed extract at $1 \%, 2 \%, 3 \%, 4 \%, 5 \%$, Thiourea at $100 \mathrm{ppm}, 200 \mathrm{ppm}, 300$ ppm, 400 ppm, 500 ppm and Chitosan at 25 ppm, 50 ppm, 100 ppm, 125 ppm, 150 ppm. Oat crop was treated with biostimulants using foliar application, at two growth stages i.e tillering and booting. Data on various agronomic and quality parameters were recorded and analyzed. Results showed that biostimulants significantly affected phenology and quality of oat. The highest green fodder yield $(872.32 \mathrm{~g})$ was observed in the pots treated with $2 \%$ Solution of seaweed extract similarly highest dry matter yield was also highest at $170.85 \mathrm{~g}$ Interestingly crude protein was highest for thiourea at $400 \mathrm{ppm}$. In each biostimulant following doses stood out both in terms of yield and quality. In case of moringa leaf extract the ratio of 1:40with $900 \mathrm{~g}$ per pot yield and $9.43 \%$ protein, for sea weed extract $2 \%$ was better than other doses with $981 \mathrm{~g}$ yield and $9.17 \%$ protein, for thiourea the 400 ppm was better than other concentrations as it shows highest yield $(872.32 \mathrm{~g})$ and crude protein $(9.52 \%)$ and for 
Gurmani, Z.A.; et al.

chitosan 100 ppm was comparatively better in performance with $964.98 \mathrm{~g}$ yield per pot and $9.35 \% \mathrm{CP}$. It is concluded from our study that biostimulants improve fodder oat yield and quality.

Keywords: fodder oat; biostimulant; organic fodder; moringa leaf extract; sea weed extract; chitosan; thiourea.

\section{INTRODUCTION}

Oat is one of the most important Rabi crop grown all over the country as forage or harvested for hay or silage both for irrigated and Barani areas in Pakistan. It is widely grown as a multi-purpose cereal in the world $[12,18]$. It may be better adapted to variable soil types and environmental conditions, performs best on acidic soils then other small grain cereal crops. Temperate and subtropical climate is favored by oat crop. Oat provides green fodder during lean period in December, January, when there is shortage of fodders[19]. Oats are now a very important winter fodder on small farms in Pakistan. Oats have changed from a minor fodder to a major crop in the past twenty years, mainly because of the availability of improved cultivars and their ability to produce green feed during the midwinter lean period.

The area under various fodder crops in the country is estimated as 2.05 million hectares and annual fodder production 45.97 million tons. The average fodder production is 23.3 tha $^{-1}$ which is too low to meet even half of the maintenance ration of 201.9 million heads of livestock in the country [26]. The reason is that less importance is given to research on fodder crops. There is a great need to conduct quality research on fodder crops to cope with climate change scenario.

Oat production is limited by various biotic and abiotic factors which results to low fodder yield and poor nutrition. After the green revolution, there is abundant use of chemical fertilizers and pesticides to get optimum yield but this injudicious use has bad effects on health and environment. Therefore there is need of using bio stimulants to get high production of crops. Thus it is imperitive to conduct research and develop package of improved oat production technology which makes it resilient to biotic stress with more green fodder production and high nutrition.

Keeping in view the above factors exogenous application of sea weed extract, moringa leaf extract, chitosan and thiourea have the beneficial effects on oat production and quality [11]. It is helpful for plants in many ways as it improves plant water status in context of relative water content and transpiration rate ameliorates the harmful effects of salinity on chlorophyll content and plant biomass [8]. These biostimulants containing macro and micro nutrients and are being widely used for crop yield improvement. Use of these biostimulants significantly improved plant growth in terms of root and shoot weight, plant height, number of leaves, leaf area, yield and quality [2, 13]. Da Silva and coauthors (2020), revealed in their study that foliar spray of biostimulants produce better crop yield as compare to other methods of application. Foliar applied nutrient also compliment band placed fertilizer and due to better ability to diffuse nutrients through leaf and other areal parts of plant because they are readily available [29, 31]. The study will not only be helpful in exploring the potential of biostimulants on oat production but also pave a way to increase fodder production organically.

\section{MATERIALS AND METHODS}

\section{Experimental Site}

The pot experiment was conducted at green house of National Institute for Genomics and Advanced Biotechnology, National Agricultural Research Centre (NARC) Islamabad, Pakistan in 2018. The site is located at $33^{\circ} 43^{\prime} \mathrm{N}$ and $73^{\circ} 04^{\prime} \mathrm{E}$ at an altitude of $540 \mathrm{~m}$ above sea level in Pothohar Plateau in the northeastern of the country. The experimental site has humid subtropical climate with mean annual rainfall $790 \mathrm{~mm}$. The pots were filled with the soil that was silty-clay and $\mathrm{pH}$ ranges from 7.3-8.4. The soil was deficient in nitrogen and contained less than one percent organic matter.

\section{Experimental Treatments}

A pot experiment was carried out for optimizations of bio stimulants i.e Moringa leaf extract, Sea weed extract, Thiourea and Chitosan on oat crop under controlled conditions in Completely Randomized Design with three replications. Each biostimulant having five concentrations i.e for Moringa leaf extract 1:10, 1:20, 1:30, 1:40, 
1:50, for Sea weed extract 1\%, 2\%, 3\%, 4\%, 5\%, for Thiourea100 ppm, 200 ppm, 300 ppm, 400 ppm, 500 ppm and for Chitosan 25 ppm, 50 ppm, 100 ppm, 125 ppm, 150 ppm. The biostimulants were foliar applied at two growth stages i.e tillering and booting.

\section{Data Collection}

Experimental observation includes number of leaves tiller-1, leaf area $\left(\mathrm{cm}^{2}\right)$, plant height $(\mathrm{cm})$, Tillers per plant,leaf weight tiller ${ }^{-1}(\mathrm{~g})$, stem weight tiller-1 $(\mathrm{g})$,leaf stem ratio, Green fodder yield $\left(\mathrm{g} \mathrm{plot}^{-1}\right)$, Dry Matter per tiller $(\%)$, Dry Matter per Plant (\%), Dry Matter yield $\left(\mathrm{g} \mathrm{plot}^{-1}\right)$, Crude Protein (\%), Crude Fiber (\%) and Ash Contents (\%). Data were collected at $50 \%$ flowering Stage. Three different plants were selected randomly to represent true samples. Meter rods, weigh balances and manual counting methods were implemented to collect the phonological data.

For chemical analysis Green samples of $500 \mathrm{~g}$ weight were collected from each experimental unit and ovendried at $100^{\circ} \mathrm{C}$ for 24 hours. Prescribed procedures of AOAC (1990) [10] were used for the assessment of crude protein (CP), crude fiber (CF), DM (\%) and ash percentage at Animal Nutrition Laboratories of the Animal Sciences Institute, NARC, Islamabad. For crude protein, digestion was done using an auto Kjeldhal system (Digest System K-437, and Auto Kjeldahl Unit K-370; Büchi) while distillation and titration were done by hand. Nitrogen percentage was used to calculate crude protein. For crude fiber (CF), a fiber analyzer (Ankom A2000I Fiber Analyzer, Ankom, Macedon, NY) was used and standard protocols were applied. For ash contents, dried samples were ignited in Muffle Furnace up to $550 \mathrm{OC}$ to burn all the organic matter and leftover was weighed as ash content. For dry matter (DM), $200 \mathrm{~g}$ oats samples were collected at $50 \%$ blossoming stage. To get rid of debris plants were rinsed with distilled water and freeze. After that samples were desiccated at $60^{\circ} \mathrm{C}$ in a hot air oven until the dry weight became constant.

\section{Statistical Analysis}

Data collected on various parameters were subjected to statistical analysis by using analysis of variance (ANOVA) technique under Completely Randomized Design. Means were compared by using least significant differences (LSD) [32].

\section{RESULT AND DISCUSSIONS}

After statistical analysis and graphical representation, it was revealed that all the pots treated with biostimulants showed a clear rise in almost all the characters including green fodder yield and crude protein as compared to control treatments. Some of the doses in every biostimulants stood out in case of most traits. For instance, 1:40 solution of moringa leaf extracts, $2 \%$ solution of seaweed extracts, 100 ppm solution of chitosan and 400 ppm solution of thiourea showed significant increase not only in fodder yield but also in quality. Trait wise results are as follows. 


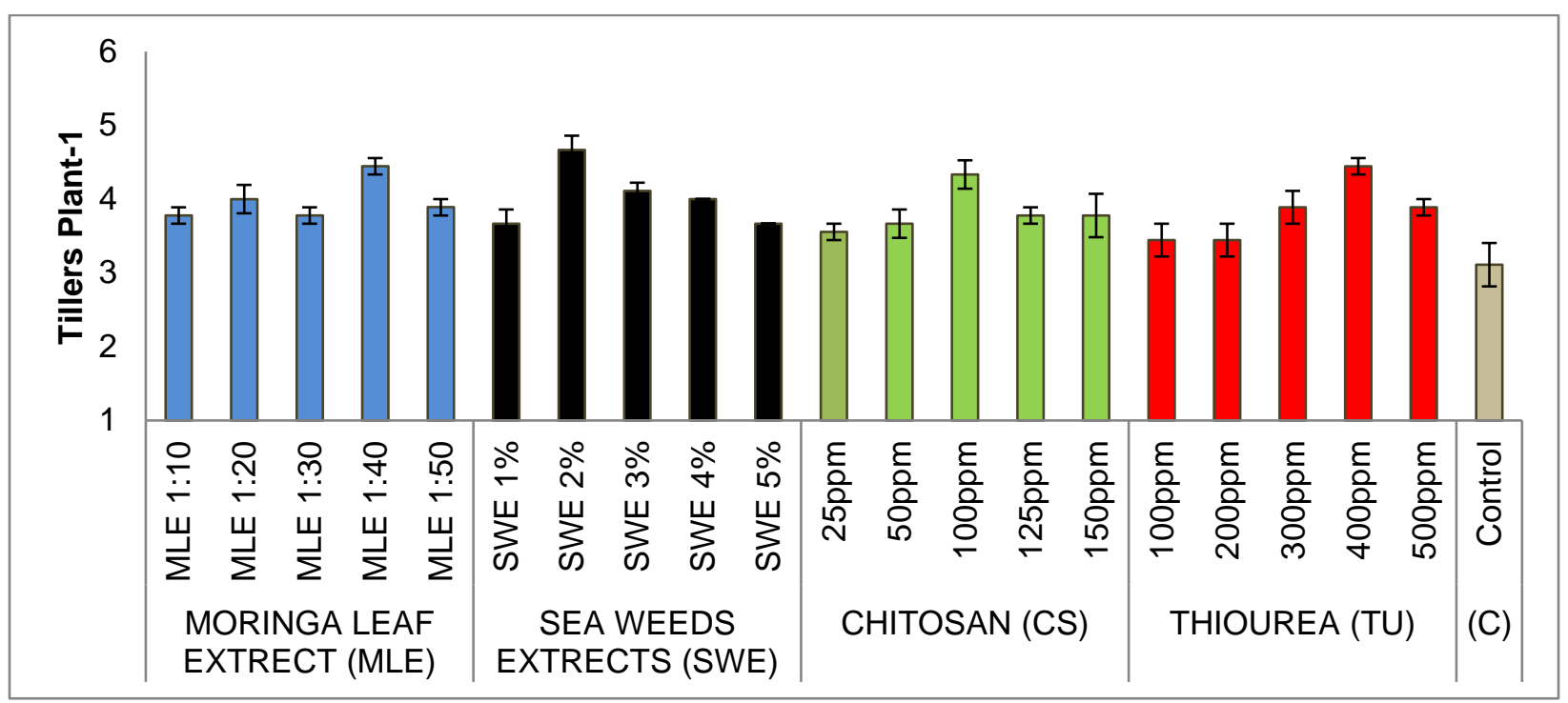

Figure 1. Tillers plant ${ }^{-1}$ of oat as affected by biostimulants and their levels.

\section{Tillers Plant ${ }^{-1}$}

Tiller plant ${ }^{-1}$ of oat were significantly affected by various biostimulants and their levels (Figure 01). Comparing control Vs rest a significant difference was noted in the tiller plant ${ }^{-1}$ as $20.45 \%$ more tiller Plant $^{-1}$ were recorded in biostimulant treated pots as compared to control. Mean values for sea weed extract (SWE) shows that among biostimulants highest tiller plant ${ }^{-1}$ (4.67) was recorded at $2 \%$ (SWE), while in case of moringa leaf extracts (MLE) maximum tiller plant ${ }^{-1}(4.44)$ were recorded at 1:40 ratio, similarly for thiourea (TU) highest tiller plant ${ }^{-1}(4.44)$ were obtained at $400 \mathrm{ppm}$ (TU) and the chitosan at $100 \mathrm{ppm}$ produced 4.33 number of tillers per plant. It is incurred from the results that tiller plant ${ }^{-1}$ was increased in treated pots as compared to control; however there was variation in the tiller plant ${ }^{-1}$ within various levels of each biostimulants. These results are also in line with Mondal and coauthors (2013).

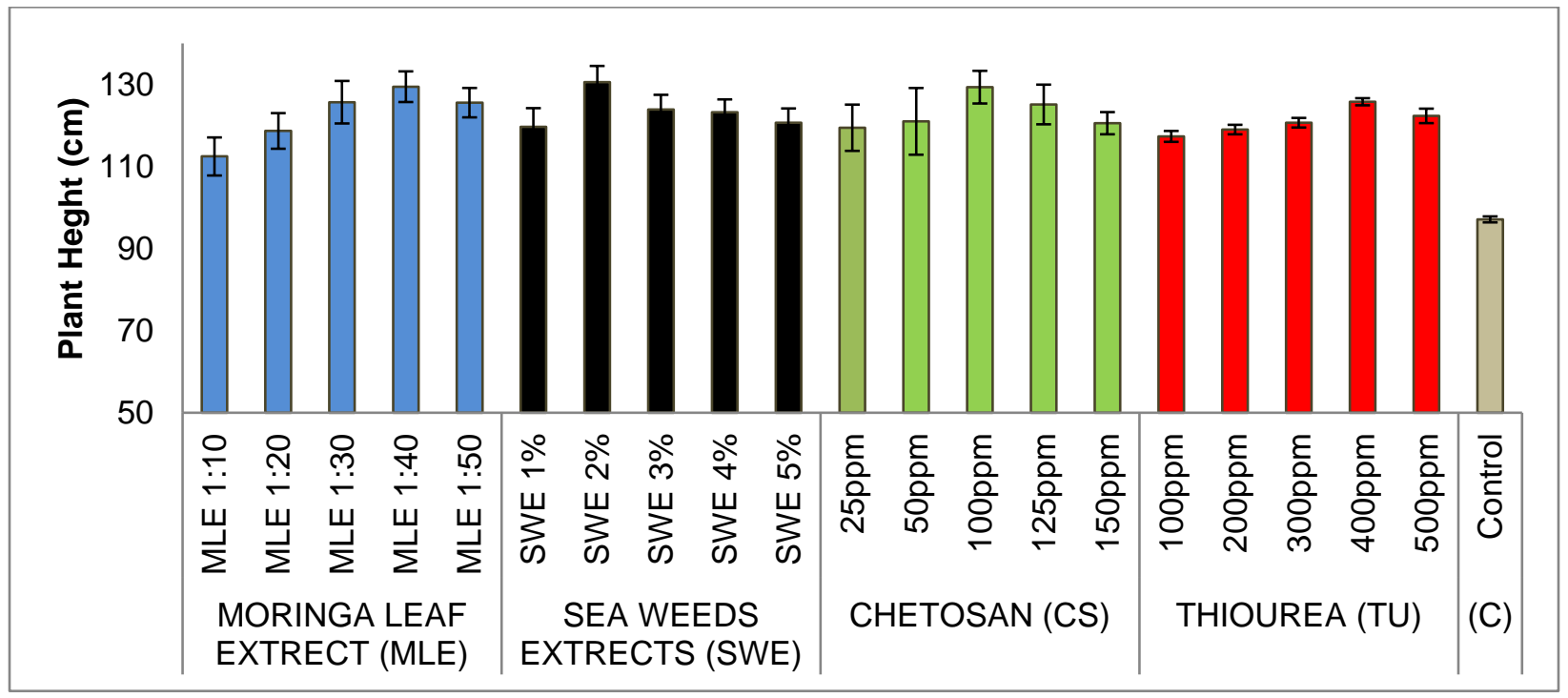

Figure 2. Plant height $(\mathrm{cm})$ of oat as affected by biostimulants and their levels.

\section{Plant Height (cm)}

Plant height of oat was significantly affected by various biostimulants and their levels (Figure 02). Comparing control Vs rest a significant difference was noted in the plant height as $20.74 \%$ more plant height was recorded 
in biostimulant pots as compared to control. Mean values for sea weed extract shows that among biostimulants highest plant height $(130.56 \mathrm{~cm}$ ) was recorded at $2 \%$ while in case of moringa leaf extract (MLE) maximum plant height $(129.44 \mathrm{~cm})$ was recorded at 1:40 ratio, similarly for chitosan $(\mathrm{CS})$ high plant height $(129.33 \mathrm{~cm})$ was noted at $100 \mathrm{ppm}$ (CS). For thiourea (TU) highest plant height $(125.78 \mathrm{~cm})$ was obtained at $400 \mathrm{ppm}(\mathrm{TU})$. It is incurred from the results that plant height was increased in treated pots as compared to control; however there was variation in the plant height within various levels of each biostimulant. The biostimulants play a vital role in the enhancement of biological yield [28]. As biostimulants play a key role in defensive mechanism in plants ,stimulation of plant growth, seed coating, frost protection and timely release of fertilizers and nutrients into the soil thus more height was observed[14].

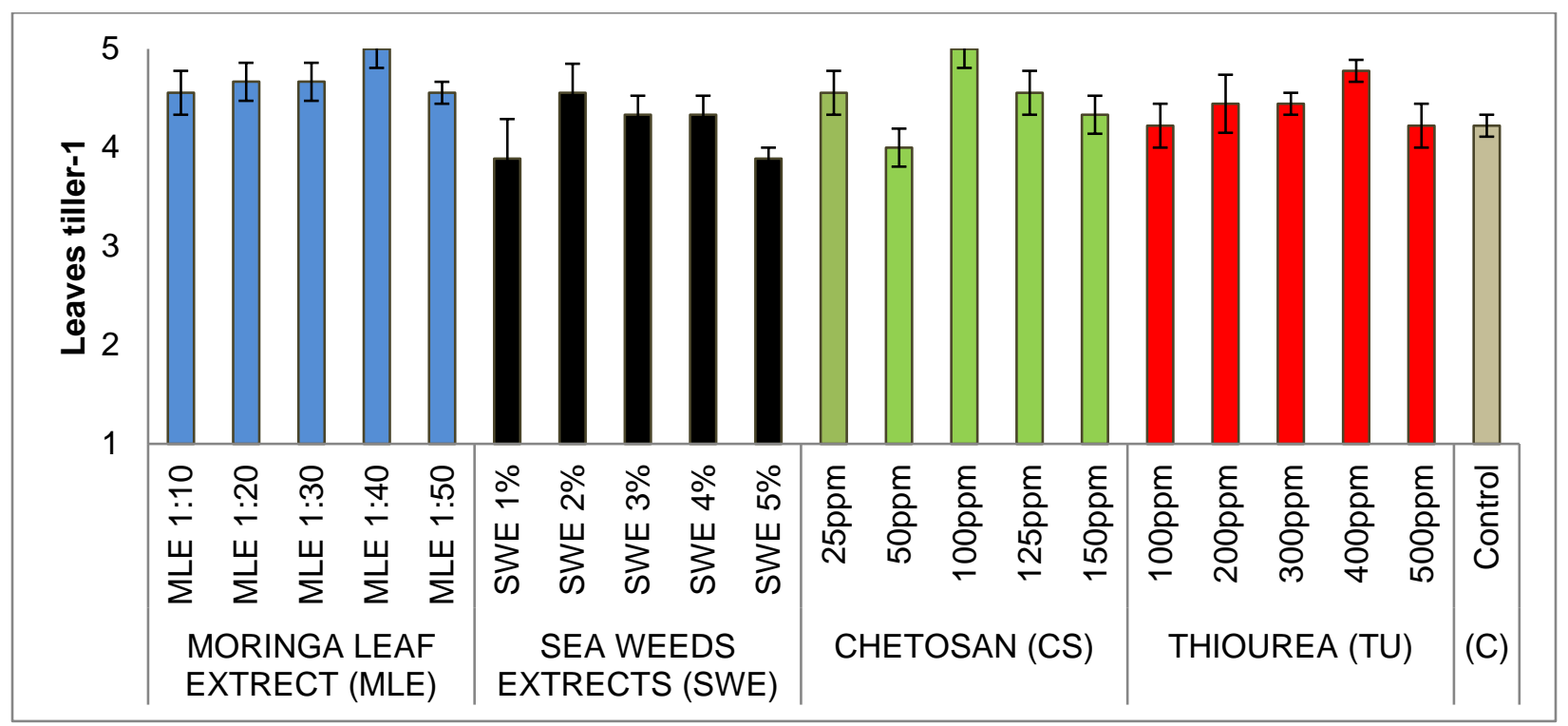

Figure 3. Leaves tiller-1 of oat as affected by biostimulants and their levels.

\section{Leaves tiller-1}

Statistical analysis of the data shows that leaves tiller-1 was significantly affected by various biostimulants and their levels (Figure 03). Comparing control Vs rest significant differences were observed in the leaves per tiller as $5.12 \%$ more leaves tiller ${ }^{-1}$ were recorded in biostimulant pots as compared to control. Mean values for chitosan (CS) shows that among biostimulants highest leaves tiller-15.00) were recorded at 100 ppm while in case of moringa leaf extracts (MLE) maximum leaves tiller ${ }^{-1}(5.00)$ were recorded at 1:40 ratios, similarly for sea weed extracts (SWE) high leaves tiller ${ }^{-1}$ (4.56) was noted at $2 \%$ SWE. For thiourea (TU) highest leaves per tiller (4.78) were obtained at $400 \mathrm{ppm}$ (TU). It is incurred from the results that leaves tiller ${ }^{-1}$ was increased in treated pots as compared to control; however there was variation in the leaves tiller ${ }^{-1}$ within various levels of each biostimulant. More leaves per tiller in treated plants may attribute to better vegetative growth as the use of biostimulants increase vegetative growth $[9,17]$. 


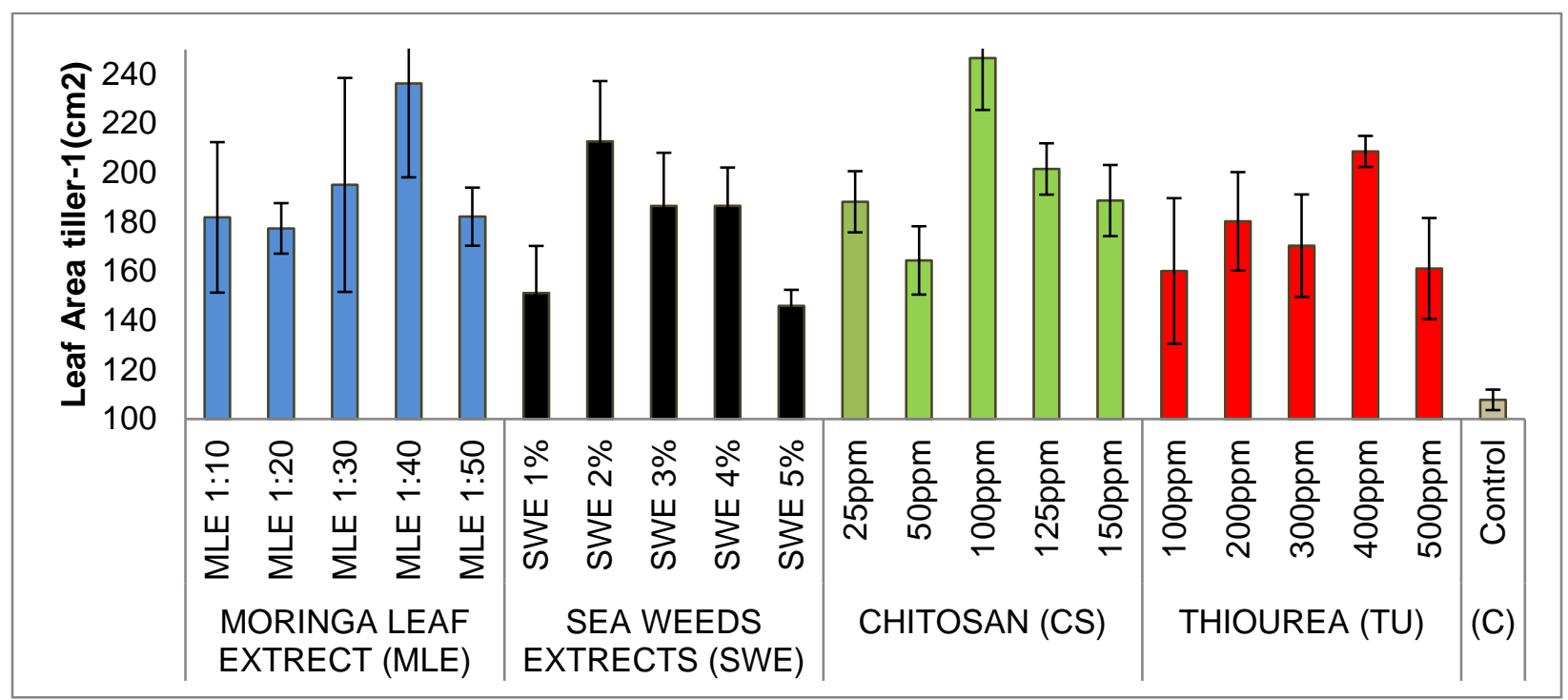

Figure 4. Leaf area $\left(\mathrm{cm}^{-2}\right)$ of oat as affected by biostimulants and their levels.

\section{Leaf Areatiller-1 $\left(\mathrm{cm}^{2}\right)$}

Leaf area tiller ${ }^{-1}$ of oat was significantly affected by various biostimulants and their levels (Figure 04). Comparing control Vs rest a significant difference was noted in the leaf area as $42.14 \%$ more leaf area was recorded in biostimulants treated pots as compared to control. Mean values for chitosan (CS) shows that highest leaf area $\left(246.58 \mathrm{~cm}^{2}\right)$ was recorded at $100 \mathrm{ppm}$ while in case of moringa leaf extracts (MLE) more leaf area $\left(236.22 \mathrm{~cm}^{2}\right)$ was recorded at 1:40 ratio, similarly for sea weed extract (SWE) high leaf area $\left(212.75 \mathrm{~cm}^{2}\right)$ was noted at $2 \%$ SWE. For thiourea (TU) highest leaf area $\left(208.68 \mathrm{~cm}^{2}\right)$ was obtained at $400 \mathrm{ppm}(T U)$. It is incurred from the results that leaf area was increased in treated pots as compared to control; however there was variation in the leaf area within various levels of each biostimulant. The increased in the leaf area is due to the fact that biostimulant improves plant vigor and efficiency of plant metabolism, nutrients assimilation and translocation. Our results are in complete agreement with ([9], who stated that with the application of biostimulants plant growth and development was enhanced. Same result were also recorded by [15,25] while comparing the biostimulants a better result obtain for leaf area of oat as sea weed play a vital role in the plant vegetative growth due to the presence of protective anti-oxidants enhance the vegetative growth of plants. These results are also in line with [7].

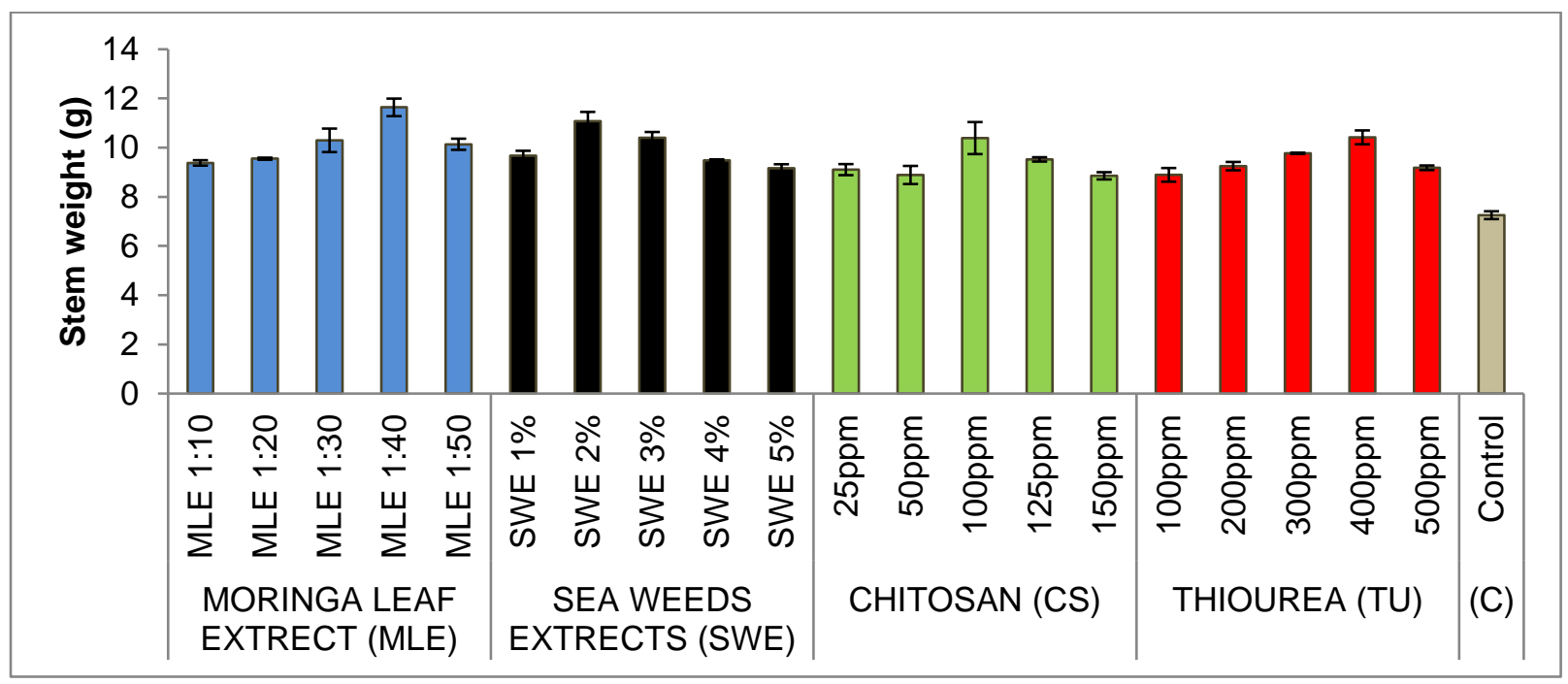

Figure 5. Stem weight (g) of oat as affected by biostimulants and their levels. 


\section{Stem weight $(g)$}

Stem weight of oat was significantly affected by various biostimulants and their levels (Figure 05). Comparing control Vs rest, the significant differences were noted in the stem weight as $25.63 \%$ more stem weight was recorded in biostimulant pots as compared to control. Mean values shows that among biostimulants highest stem weight $(11.64 \mathrm{~g})$ was recorded for moringa leaf extract (MLE) 1:40. While in case of sea weed extract (SWE) at $2 \%$ concentration the stem weight $(11.06 \mathrm{~g})$ was higher than other levels. Similarly for thiourea (TU) highest stem weight (10.42 g) was obtained at $400 \mathrm{ppm}$ (TU). For chitosan (CS) high stem weight (10.39) was noted at 100 ppm. It is incurred from the results that stem weight was increased in treated pots as compared to control; however there was variation in the stem weight within various levels of each biostimulant. Biostimulants increased stem weight due to the possible reason that they contains bioactive compounds which improve plant growth and biomass yield [8, 16, 20].

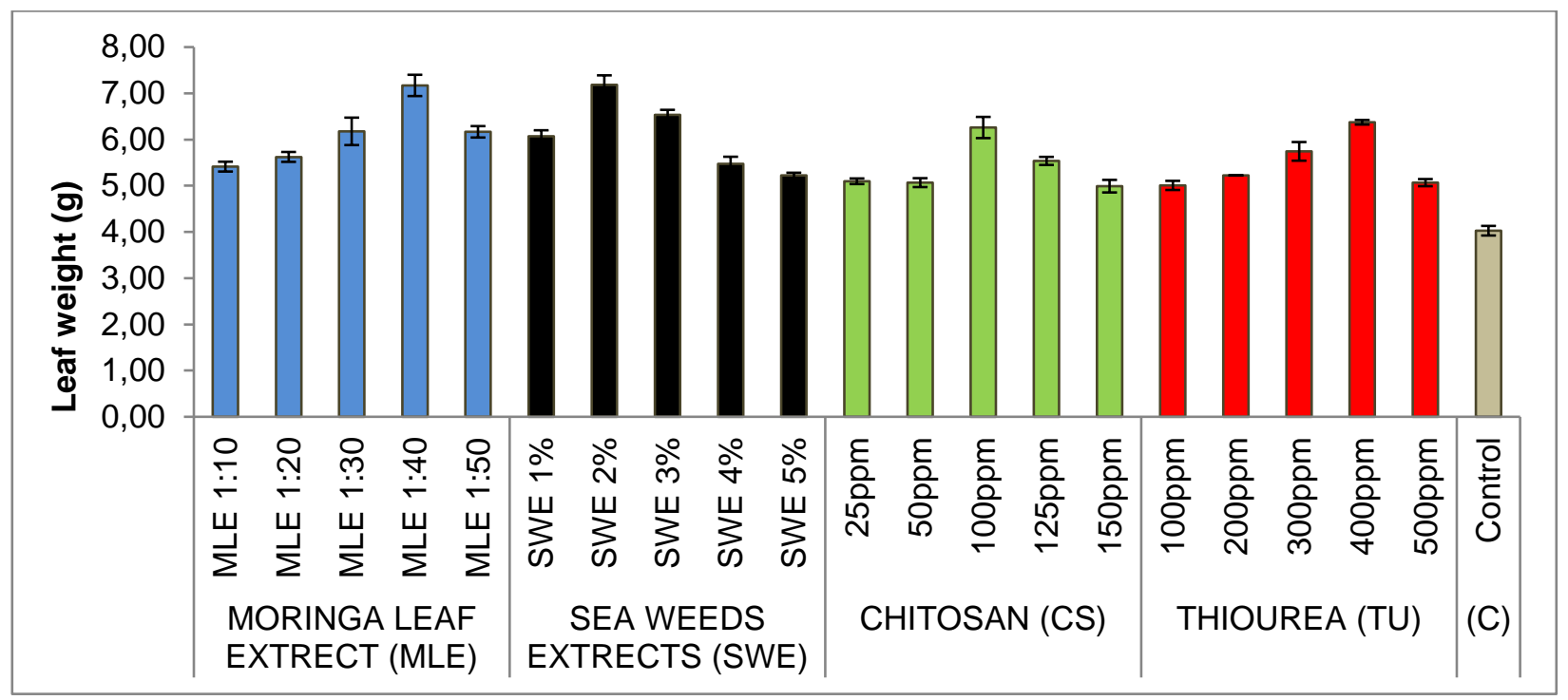

Figure 6. Leave weight $(\mathrm{g})$ of oat as affected by biostimulants and their levels.

\section{Leaf weight $(g)$}

Leaf weight of oat was significantly affected by various biostimulants and their levels (Figure 06). Comparing control Vs rest a significant difference was noted in the leaf weight as $30.21 \%$ more leaf weight was recorded in biostimulant pots as compared to control. Mean values for sea weed extract shows that among biostimulants highest leaf weight $(7.18 \mathrm{~g})$ was recorded at $2 \%$ SWE while in case of moringa leaf extract (MLE) maximum leaf weight $(7.17 \mathrm{~g})$ was recorded at 1:40 ratio which is statistically at par with sea weed extract, similarly for thiourea (TU) high leaf weight $(6.37 \mathrm{~g})$ was noted at $400 \mathrm{ppm}$. For chitosan (CS) highest leaf weight $(6.26 \mathrm{~g})$ was obtained at $100 \mathrm{ppm}$ (CS). It is incurred from the results that leaf weight was increased in treated pots as compared to control; however there was variation in the leaf weight within various levels of each biostimulant. Sea weed play a vital role in the plant vegetative growth due to the presence of protective anti-oxidants $[1,5,6]$. 


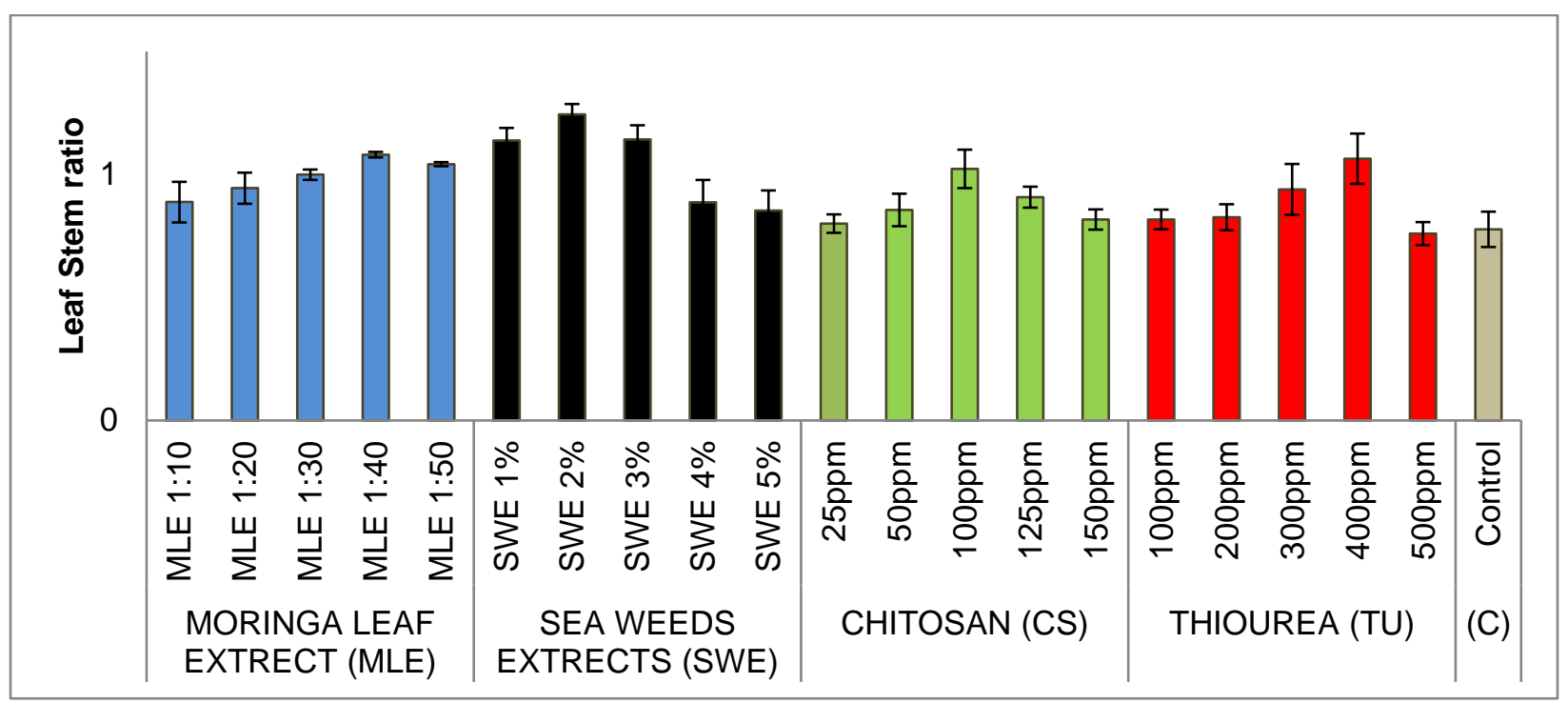

Figure 7. Leaf stem ratio of oat as affected by biostimulants and their levels.

\section{Leaf Stem Ratio}

Leaf stem ratio of oat was significantly affected by various biostimulants and their levels (Figure 07). Comparing control Vs rest a significant difference was noted in the leaf stem ratio as $5.90 \%$ more leaf stem ratio was recorded in biostimulant pots as compared to control. Mean values for sea weed extract (SWE) shows that among biostimulants highest leaf stem ratio $(0.65)$ was recorded at $2 \%$ while in case of moringa leaf extracts (MLE) maximum leaf stem ratio (0.62) was recorded at 1:40 ratio, similarly for thiourea (TU) highest leaf stem ratio $(0.61)$ was obtained at $400 \mathrm{ppm}(\mathrm{TU})$. For chitosan high leaf stem ratio $(0.60)$ was noted at $100 \mathrm{ppm} \mathrm{CS}$. It is incurred from the results that leaf stem ratio was increased in treated pots as compared to control; however there was variation in the stem weight within various levels of each biostimulant. The increased in the leaf stem ratio is due to the fact that biostimulant improves plant vigor and efficiency of plant metabolism, nutrients assimilation and translocation [2, 27].

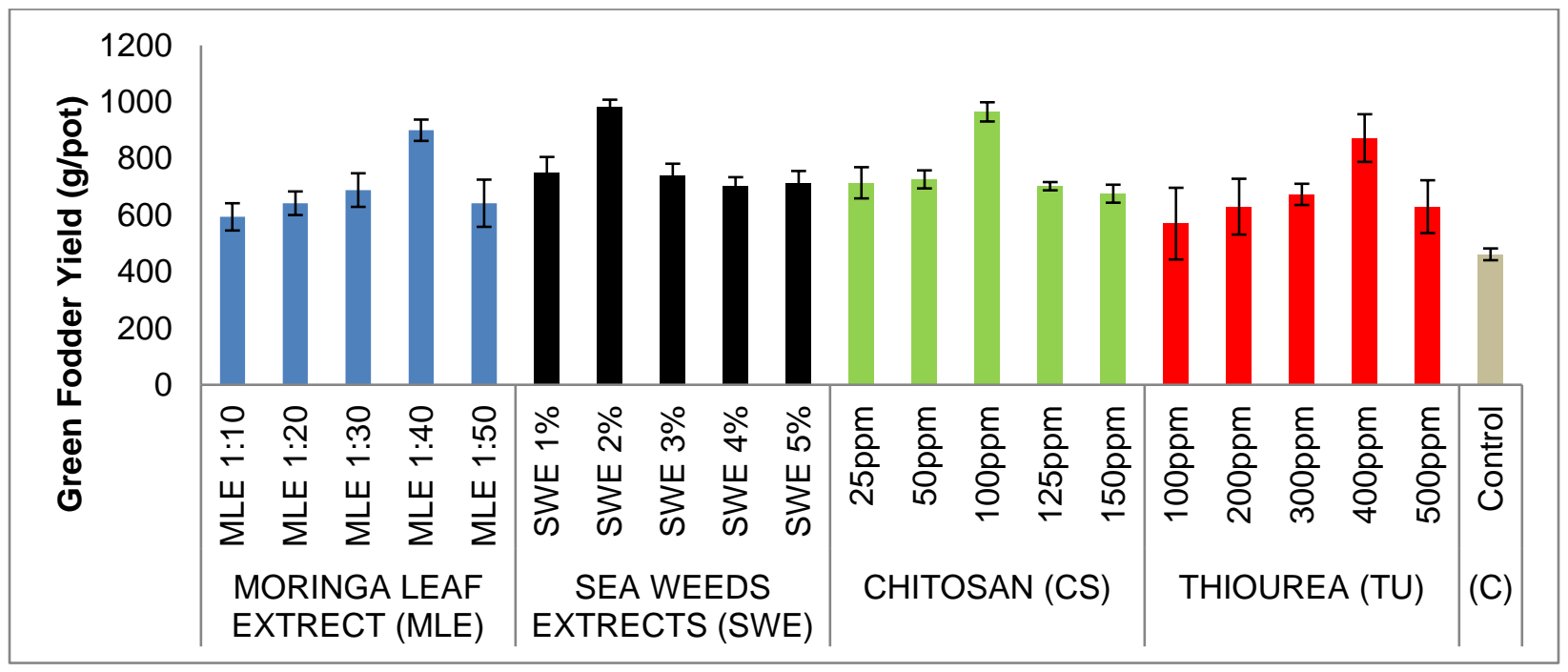

Figure 8. Green Fodder Yield of oat as affected by biostimulants and their levels. 


\section{Green fodder yield (g/pot)}

Green fodder yield of oat was significantly affected by various biostimulants and their levels (Figure 8). Comparing control Vs rest a significant difference was noted in the GFY as $36.42 \%$ more yield was recorded in biostimulant pots as compared to control. Mean values for sea weed extract (SWE) shows that among biostimulants highest GFY (981.89 $\mathrm{g} \mathrm{pot}^{-1}$ ) was recorded at $2 \%$ while in case of chitosan (CS) maximum GFY (964.98 $\left.\mathrm{g} \mathrm{pot}^{-1}\right)$ was recorded at $100 \mathrm{ppm}(\mathrm{CS})$, similarly for moringa leaf extracts (MLE) high yield (900.01 g pot $^{-1}$ ) was noted at 1:40 ratio. For thiourea (TU) highest yield (872.32 $\left.\mathrm{g} \mathrm{pot}^{-1}\right)$ was obtained at $400 \mathrm{ppm}(\mathrm{TU})$. It is incurred from the results that green fodder yield was increased in treated pots as compared to control; however there was variation in the yield within various levels of each biostimulants. GFY accumulation in fodder crops depends on vegetative growth [4]. The biostimulants affect the cellular metabolism of the plants which is based on physiological actions of vitamins; therefore have positive effect on the crop plants because the photosynthetic efficiency increased which enhances the yield $[2,3]$.

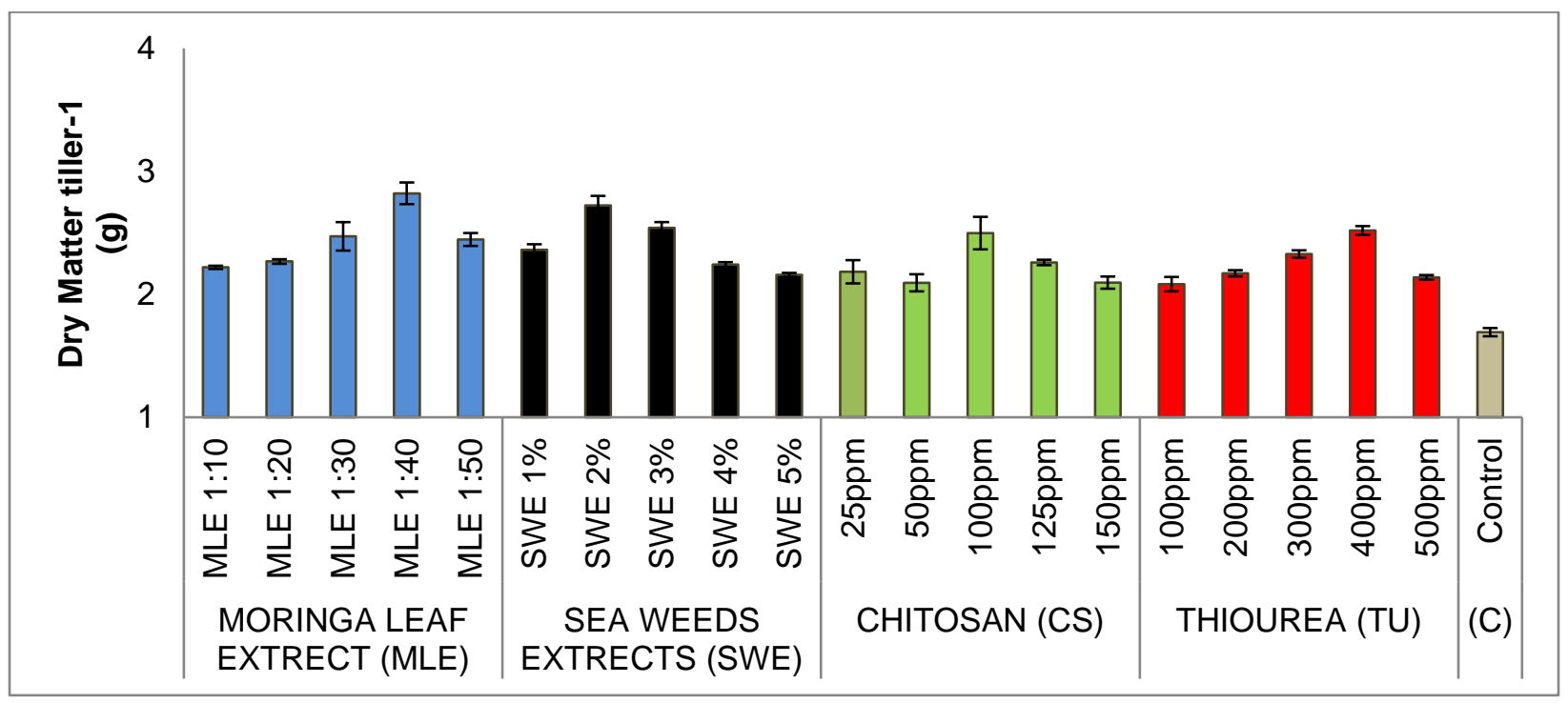

Figure 9. Dry matter tiller-1 of oat as affected by biostimulants and their levels.

\section{Dry Matter tiller-1}

Dry matter tiller ${ }^{-1}$ of oat was significantly affected by various biostimulants and their levels (Figure 09). Comparing control Vs rest a significant difference was noted in the dry matter tiller ${ }^{-1}$ as $27.39 \%$ more dry matter was recorded in biostimulant pots as compared to control. Mean values for moringa leaf extract (MLE) shows that among biostimulants highest dry matter tiller ${ }^{-1}(2.82 \mathrm{~g})$ was recorded at 1:40 ratios while in case of sea weed extracts (SWE) maximum dry matter tiller ${ }^{-1}(2.72 \mathrm{~g})$ was recorded at $2 \%$ SWE, similarly for thiourea (TU) highest dry matter tiller ${ }^{-1}(2.52 \mathrm{~g})$ was obtained at $400 \mathrm{ppm}(\mathrm{TU})$. For chitosan (CS) highest dry matter tiller $\mathrm{r}^{-1}(2.50 \mathrm{~g})$ was obtained at $100 \mathrm{ppm}$ (CS). It is incurred from the results that dry matter tiller ${ }^{-1}$ was increased in treated pots as compared to control; however there was variation in the dry matter within various levels of each biostimulant [19, 21]. 


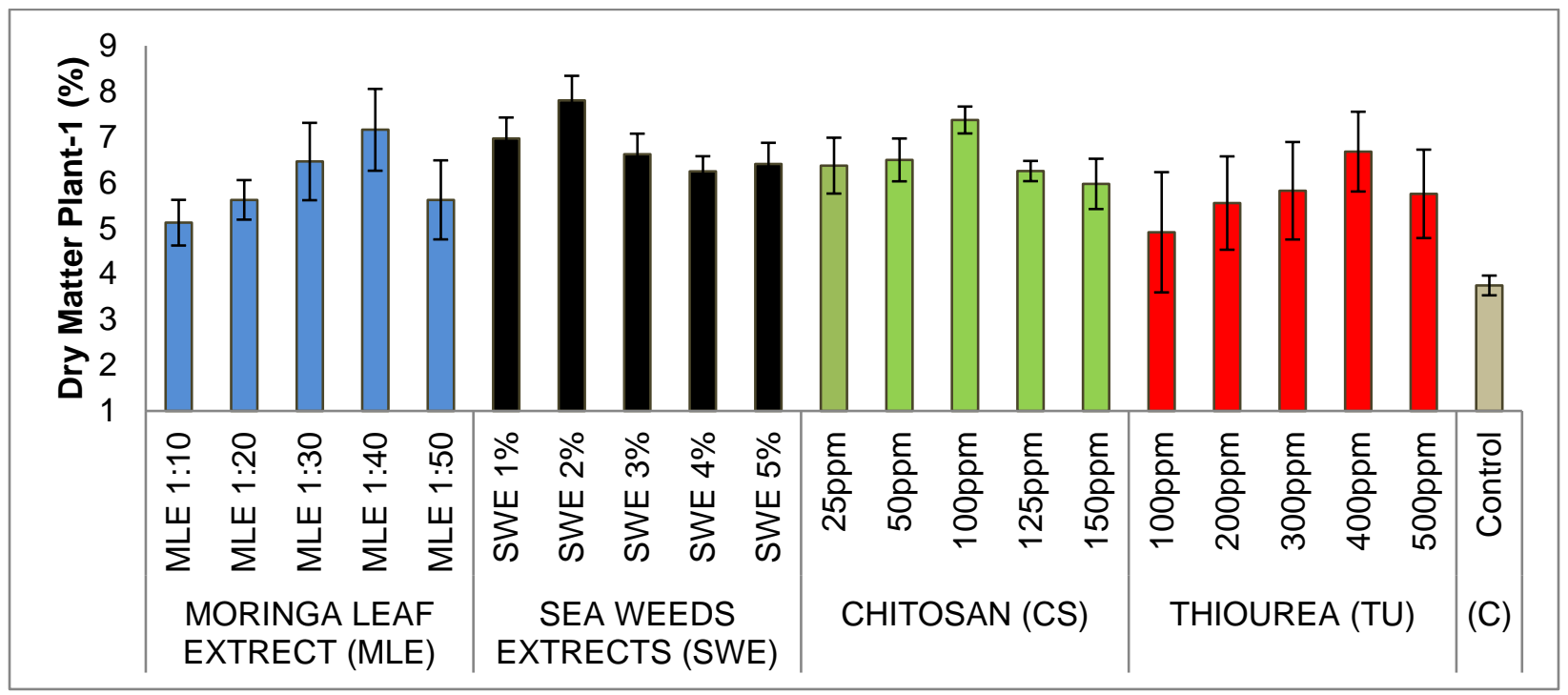

Figure 10. Dry matter (\%) of oat as affected by biostimulants and their levels.

\section{Dry Matter Plant ${ }^{-1}$ (\%)}

Dry matter of oat was significantly affected by various biostimulants and their levels (Figure 10). Comparing control Vs rest, significant differences were noted in the dry matter as $42.8 \%$ more dry matter was recorded in biostimulant pots as compared to control. Mean values for sea weed extract shows that among biostimulants highest dry matter (13.29\%) was recorded at $2 \%$ SWE, while in case of moringa leaf extract (MLE) maximum dry matter $(13.06 \%)$ was recorded at 1:40 ratio, similarly for thiourea high dry matter $(11.64 \%)$ was noted at $400 \mathrm{ppm}$. For chitosan (CS) highest dry matter (11.28\%) was obtained at $100 \mathrm{ppm}(\mathrm{CS})$. It is incurred from the results that dry matter was increased in treated pots as compared to control; however there was variation in the dry matter within various levels of each biostimulant. Dry matter accumulation in fodder crops depends on vegetative growth [4].

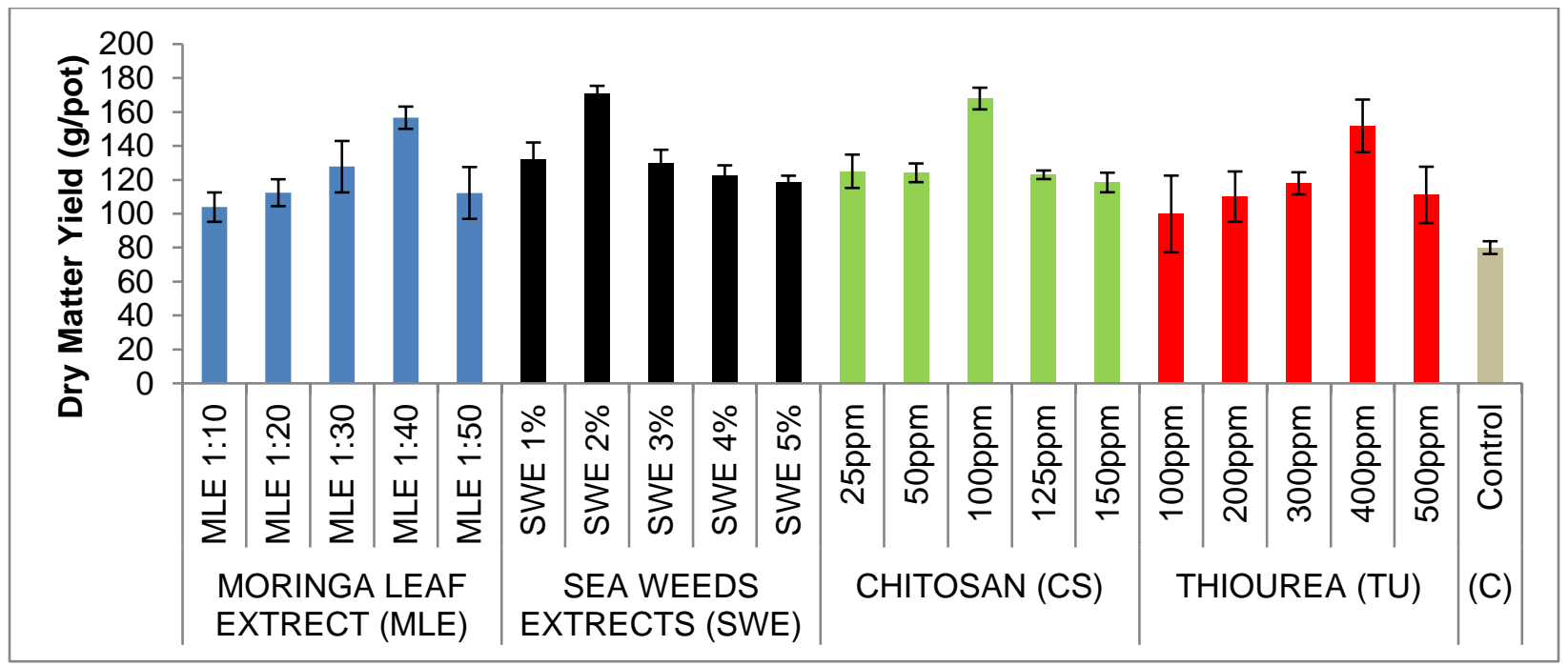

Figure 11. Dry matter Yield of oat as affected by biostimulants and their levels.

\section{Dry Matter yield (g/pot)}

Dry matter of oat was significantly affected by various biostimulants and their levels (Figure 11). Comparing control Vs rest a significant difference was noted in the dry matter yield as $36.88 \%$ more dry matter was recorded in biostimulant pots as compared to control. Mean values for sea weed extract (SWE) shows that among 
biostimulants highest dry matter (170.85 $\left.\mathrm{g} \mathrm{pot}^{-1}\right)$ was recorded at $2 \%$ (SWE) while in case of chitosan (CS) maximum dry matter (167.91 $\left.\mathrm{g} \mathrm{pot}^{-1}\right)$ was recorded at $100 \mathrm{ppm}$, the moringa leaf extracts (MLE) produced maximum dry matter $\left(156.60 \mathrm{~g} \mathrm{pot}^{-1}\right)$ and was recorded at 1:40 ratio. For thiourea (TU) highest dry matter (151.78 $\mathrm{g} \mathrm{pot}^{-1}$ ) was obtained at $400 \mathrm{ppm}$ (TU). It is incurred from the results that dry matter was increased in treated pots as compared to control; however there was variation in the dry matter within various levels of each biostimulant. Dry matter is accumulation in fodder crops depends on vegetative growth [4, 23].

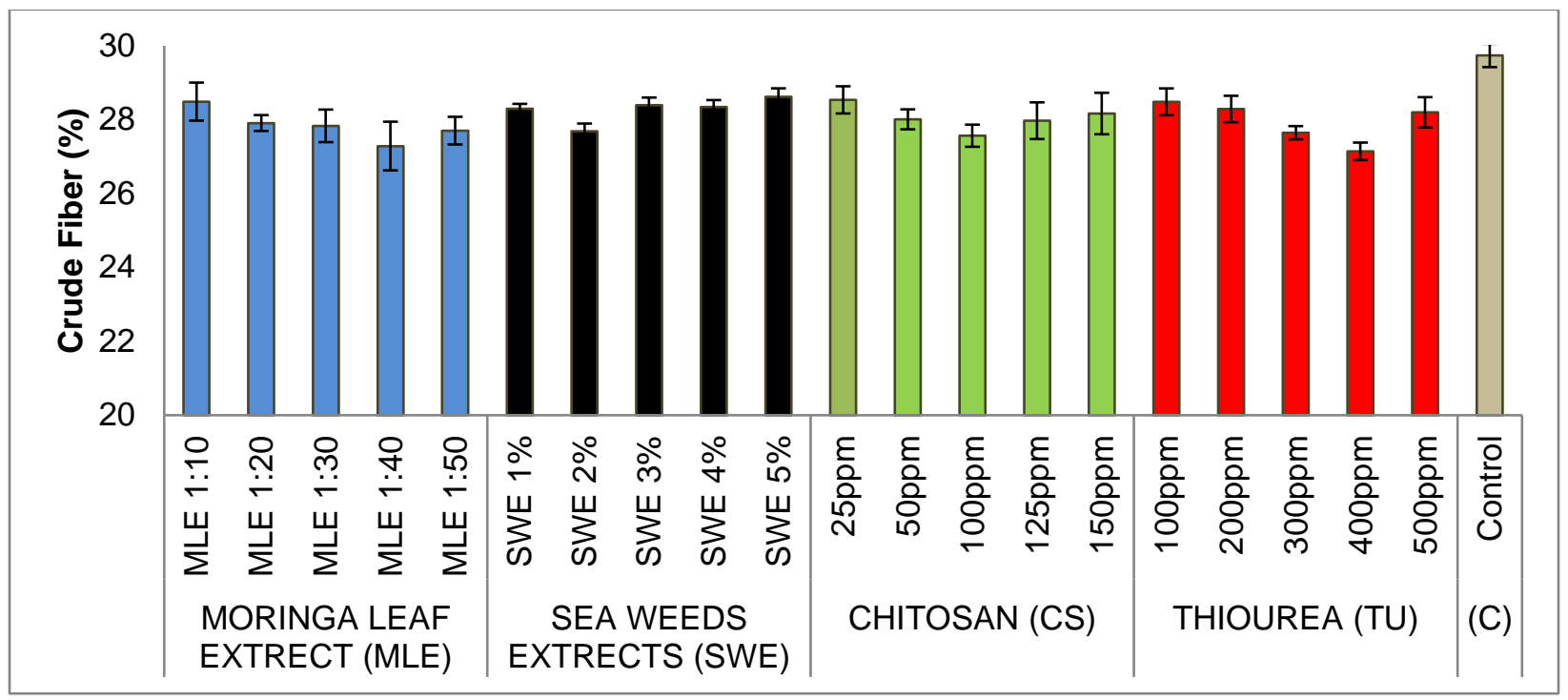

Figure 12. Crud fiber (\%) of oat as affected by biostimulants and their levels.

\section{Crude Fiber (\%)}

Crude fiber of oat was significantly affected by various biostimulants and their levels (Figure 12). Comparing control Vs rest a significant differences $6.10 \%$ more crude fiber was recorded in control as compared to biostimulant pots. Mean values for thiourea (TU) shows that among biostimulants lowest crude fiber (27.14\%) was recorded at 400 ppm while in case of moringa leaf extract (MLE) the minimum crude fiber (27.29 \%) was recorded at 1:40 ratio, similarly for sea weed extract (SWE) the lowest crude fiber (27.69\%) was noted at $2 \%$ SWE. For thiourea (TU) the less crude fiber (27.14\%) was obtained at $400 \mathrm{ppm}$ (TU). It is incurred from the results that crude fiber was decreased in treated pots as compared to control; however there was variation in the crude fiber within various levels of each biostimulant. The less percentage of crude fiber shows the best quality of the fodder [1]. 


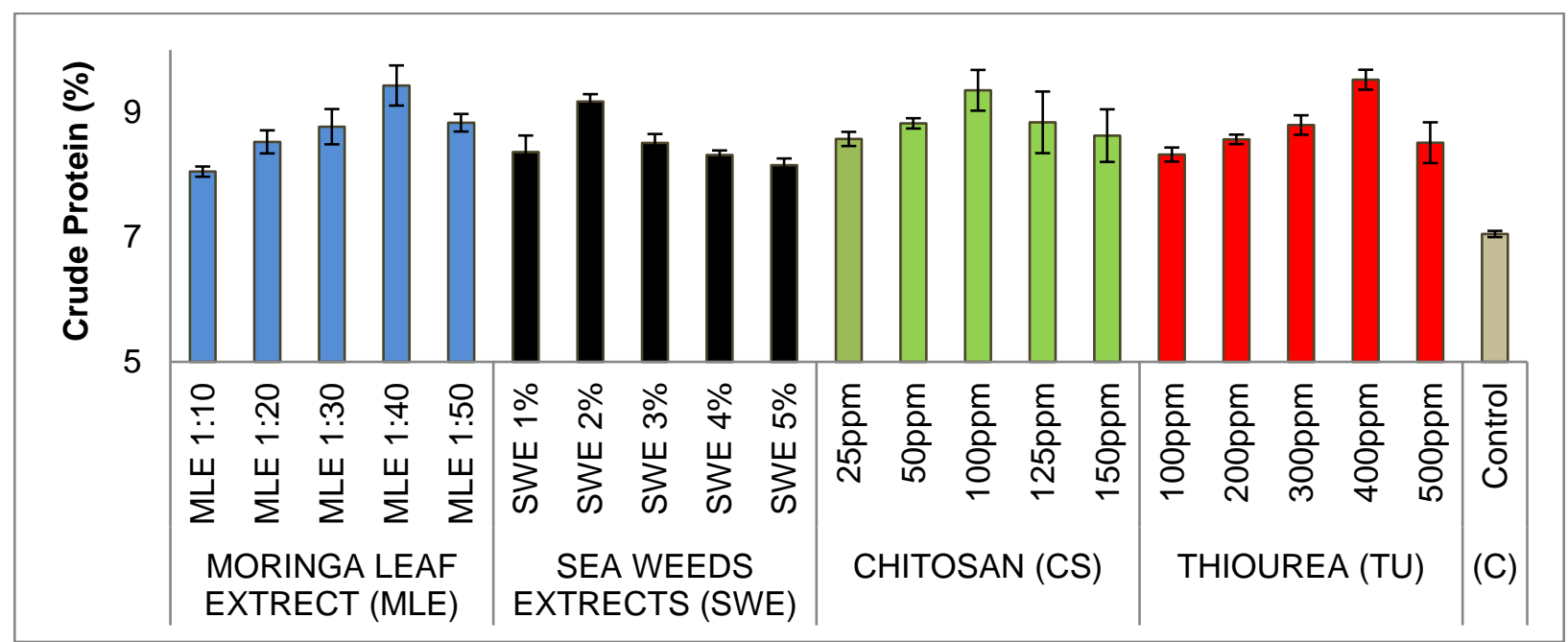

Figure 13. Crud protein (\%) of oat as affected by biostimulants and their levels.

\section{Crude Protein (\%)}

Crude protein of oat was significantly affected by various biostimulants and their levels (Figure 13). Comparing control Vs rest a significant differences were recorded as $18.99 \%$ more crude protein was observed in treated pots as compared to control pots. Mean values for thiourea (TU) shows that among biostimulants highest crude protein $(9.52 \%)$ was recorded at 400 ppm while in case of moringa leaf extracts (MLE) maximum crude protein $(9.43 \%)$ was recorded at 1:40 ratios, similarly for seaweed extracts (SWE) high crude protein $(9.17 \%)$ was noted at $2 \%$ SWE. For chitosan (CS) highest crude protein (9.35\%) was obtained at 100 ppm (CS). It is incurred from the results that crude protein was increased in treated pots as compared to control; however there was variation in the crude protein within various levels of each biostimulant. Crude protein is one of the most important trait in oat which plays a key role in animal nutrition thus it is always a desired characteristic which determined the quality of oat, by using biostimulants this quality may be boosted as shown in results $[1,22$, 30].



Figure 14. Ash (\%) of oat as affected by biostimulants and their levels. 


\section{Ash (\%)}

Statistical analysis of the data shows that ash (\%) was significantly affected by various Biostimulants and their levels (Figure 14). Comparing control Vs rest significant differences were recorded in treated pots as compared to control pots as $10.53 \%$ more ash was present in treated plots. Mean values for sea weed extract (SWE) shows that among biostimulants highest ash (10.59\%) was recorded at $2 \%$ SWE, while in case of chitosan (CS) maximum ash (9.87\%) was recorded at 100 ppm, similarly for moringa leaf extracts (MLE) high ash (9.83 $\%$ ) was noted at 1:40 ratio MLE. For thiourea (TU) highest ash (9.77\%) was obtained at $400 \mathrm{ppm}$ (TU). It is incurred from the results that ash percentage was increased in treated pots as compared to control; however there was variation in the ash within various levels of each biostimulant. Our results are considering with Nardi and coauthors (2009) who stated that biostimulants can act directly on the plant physiology and metabolism or by improving the soil conditions [24, 33].

\section{CONCLUSION}

It is concluded from the present study that moringa leaf extract in the ratio of 1:40 performed better by increasing vegetative growth and quality of oat as compared to other ratios, for sea weed extract $2 \%$ was better than other doses, for thiourea the 400 ppm was better than other concentrations and for chitosan 100 ppm was comparatively better in performance.

Funding: "This research received no external funding"

Acknowledgments:The authors acknowledge the role of Vice chancellor University of Haripur for providing support at every step of this research. The authors are also thankful to Director General National Agricultural Research Center Islamabad for providing utmost support in providing land and field operations during the research period.

Conflicts of Interest: "The authors declare no conflict of interest."

\section{REFERENCES}

1. Abbas SM. The influence of biostimulants on the growth and on the biochemical composition of Vicia faba CV. Giza 3 beans. Romanian Biotechnological Letters. 2013;18(2):8061-8.

2. Abdalla MM. The potential of Moringa oleifera extract as a biostimulant in enhancing the growth, biochemical and hormonal contents in rocket (Eruca vesicaria subsp. sativa) plants. Int. J. Plant Physiol. Biochem. 2013;5(3):42-9.

3. Ahmed S, Ahmad M, Ikram S. Chitosan: a natural antimicrobial agent-a review. J. Appl. Chem. 2014;3(2):493-503.

4. Amanda A, Ferrante A, Valagussa M, Piaggesi A, editors. Effect of biostimulants on quality of baby leaf lettuce grown under plastic tunnel. International Symposium on Strategies Towards Sustainability of Protected Cultivation in Mild Winter Climate 807; 2008.

5. Apel K, Hirt H. Reactive oxygen species: metabolism, oxidative stress, and signal transduction. Annu Rev Plant Biol. 2004;55:373-99.

6. Bartwal A, Mall R, Lohani P, Guru S, Arora S. Role of secondary metabolites and brassinosteroids in plant defense against environmental stresses. J. Plant Growth Regul. 2013;32(1):216-32.

7. Beecher GR. Phytonutrients' role in metabolism: effects on resistance to degenerative processes. Nutrition Reviews. 1999;57(9):3-6.

8. Berlyn G, Russo R. The use of organic biostimulants to promote root growth. Belowground Ecol. 1990;2:12-3.

9. Bulgari R, Cocetta G, Trivellini A, Vernieri P, Ferrante A. Biostimulants and crop responses: a review. Biological Agriculture \& Horticulture. 2015;31(1):1-17.

10. Chemists AOA, Cunniff P. Official Methods of Analysis Association of Official Analytical Chemists. Washington, DC. 1990.

11. Da Silva JAG, De Mamann ATW, Scremin OB, Carvalho IR, Pereira LM, de Lima ARC, et al. Biostimulants in the indicators of yield and industrial and chemical quality of oat grains. Journal of Agricultural Studies. 2020;8(2):68-87.

12. Dornelles EF, Kraisig AR, Da Silva JA, Sawicki S, Roos-Frantz F, Carbonera R. Artificial intelligence in seeding density optimization and yield simulation for oat. Revista Brasileira de Engenharia Agrícola e Ambiental. 2018;22(3):183-8.

13. Durand N, Briand X, Meyer $C$. The effect of marine bioactive substances (N PRO) and exogenous cytokinins on nitrate reductase activity in Arabidopsis thaliana. Physiologia Plantarum. 2003;119(4):489-93. 
14. Ertani A, Nardi S, Altissimo A, editors. Long-term research activity on the biostimulant properties of natural origin compounds. I World Congress on the Use of Biostimulants in Agriculture 1009; 2012.

15. Gajc-Wolska J, Spiżewski T, Grabowska A, editors. The effect of seaweed extracts on the yield and quality parameters of broccoli (Brassica oleracea var. cymosa L.) in open field production. I World Congress on the Use of Biostimulants in Agriculture 1009; 2012.

16. Hamza B, Suggars A. Biostimulants: myths and realities. TurfGrass Trends. 2001;8:6-10.

17. Havaux M. Carotenoid oxidation products as stress signals in plants. The Plant J. 2014;79(4):597-606.

18. Hawerroth MC, Silva JAGd, Souza CA, Oliveira ACd, Luche HdS, Zimmer CM, et al. Redução do acamamento em aveia-branca com uso do regulador de crescimento etil-trinexapac. Pesquisa agropecuária brasileira. 2015;50(2):11525.

19. Hussain A, Khan S, Zahid MS, Shafeeq S, Ali Z. A new high yielding oat variety for fodder in the rainfed potohar and irrigated areas of Pakistan. Science Technology and Development (Pakistan). 2011.

20. Kauffman GL, Kneivel DP, Watschke TL. Effects of a biostimulant on the heat tolerance associated with photosynthetic capacity, membrane thermostability, and polyphenol production of perennial ryegrass. Crop Science. 2007;47(1):2617.

21. Khan W, Rayirath UP, Subramanian S, Jithesh MN, Rayorath P, Hodges DM, et al. Seaweed extracts as biostimulants of plant growth and development. J.Plant Growth Regul. 2009;28(4):386-99.

22. Marolli A, da Silva J, Sawicki S, Binelo M, Scremin A, Reginatto D, et al. A simulação da biomassa de aveia por elementos climáticos, nitrogênio e regulador de crescimento. Arq. Bras. Med. Vet. Zootec. 2018;70(2):535-44.

23. Mondal M, Puteh A, Dafader N, Rafii M, Malek M. Foliar application of chitosan improves growth and yield in maize. J Food Agric Environ. 2013;11(2):520-3.

24. Nardi S, Carletti P, Pizzeghello D, Muscolo A. Biological activities of humic substances. Biophysico-chemical processes involving natural nonliving organic matter in environmental systems. 2009;2(part 1):305-39.

25. Norrie J, Keathley J, editors. Benefits of ascophyllum nodosum marine-plant extract applications to Thompson Seedless grape production. X International Symposium on Plant Bioregulators in Fruit Production 727; 2005.

26. Pakistan Go. Economic Survey of Pakistan. In: Finance Mo, editor. Islamabad: Economic Advisor's Wing Ministry of Finance; 2019-20.

27. Quattrini E, Penati M, Alberici A, Martinetti L, Marino Gallina P, Ferrante A, et al., editors. Effect of the reduction of nutrient solution concentration on leafy vegetables quality grown in floating system. International Symposium on High Technology for Greenhouse System Management: Greensys 2007 801; 2007.

28. Rady MM, Mohamed GF. Modulation of salt stress effects on the growth, physio-chemical attributes and yields of Phaseolus vulgaris L. plants by the combined application of salicylic acid and Moringa oleifera leaf extract. Sci. Hortic. 2015;193:105-13.

29. Sharma HS, Fleming C, Selby C, Rao J, Martin T. Plant biostimulants: a review on the processing of macroalgae and use of extracts for crop management to reduce abiotic and biotic stresses. J. Appl. Phycol. 2014;26(1):465-90.

30. Shintate Galindo F, Teixeira Filho M, Carvalho M, Buzetti S, José Alves C, de Paula Garcia CM, et al., editors. Extrato de algas como bioestimulante na nutrição e produtividade do trigo irrigado na região de Cerrado. Colloquium Agrariae; 2019.

31. Smilkova M, Smilek J, Kalina M, Klucakova M, Pekar M, Sedlacek P. A simple technique for assessing the cuticular diffusion of humic acid biostimulants. Plant methods. 2019;15(1):83.

32. Steel RG, Torrie JH, Dickey DA. Principles and procedures of statistics: A biological approach: McGraw-Hill; 1997.

33. Vernieri P, Borghesi E, Ferrante A, Magnani G. Application of biostimulants in floating system for improving rocket quality. J. Food. Agric. Environ. 2005;3(3/4):86. 